\title{
Quarenta anos retratando a deficiência enquadres e enfoques da literatura infantojuvenil brasileira
}

\author{
ALESSANDRA SANTANA SOARES E BARROS
}

Universidade Federal da Bahia, Salvador, BA, Brasil

\section{RESUMO}

Trata-se de pesquisa que analisou, segundo os pressupostos da Escola Francesa de Análise do Discurso, cento e cinquenta livros infantis, editados nos últimos quarenta anos, que retrataram a deficiência. Constatou-se que os livros das décadas de 1970 e 1980 eram de escritores profissionais e mais independentes ideologicamente. Autores brasileiros, que a partir da década de 1990 escreveram sobre o tema para crianças e adolescentes, eram escritores iniciantes que retiraram autoridade na experiência vivida com a deficiência. Centraram seus propósitos na oferta de informação científica e na veiculação de mensagens moralizadoras. Tal engajamento político se deu em detrimento da melhor execução estética das obras literárias, que não preservaram premissas artísticas. As informações técnicas comprometeram a prioridade lúdica da literatura e não foram bem-sucedidas, pois incorreram em equívocos conceituais graves. Esta investigação se justificou pela contribuição semiótica à critica literária e pelo uso aplicado de seus resultados no ajuste dos parâmetros que elegem os livros infantis distribuídos às escolas públicas pelo Ministério da Educação.

PALAVRAS-CHAVE

literatura infantil; pessoa com deficiência; análise do discurso. 


\title{
FORTY YEARS PICTURING DISABILITY: FRAMINGS AND APPROACHES TO BRAZILIAN CHILDREN'S LITERATURE
}

\begin{abstract}
The research analyzed, according to the assumptions of the French School of Discourse Analysis, one hundred and fifty children's book, published in the last forty years, which depicted disability. It was found that the books from the seventies and eighties, whose authors were professional writers, are more ideologically independent. Brazilian authors, that started writing for children and adolescents in the nineties and then portrayed disability in their books, were amateur writers that took the authority from their own experience with disability. They, thus, focused their purposes on the provision of scientific information and on bringing moralizing messages about the ideal behavior toward people with disabilities. This political engagement was to the cost of the quality of these works, which have not preserved their artistic integrity. The technical information compromised the playful aims of the literature and the books were not successful because of these serious conceptual errors. This investigation was justified by the semiotic contribution to literary criticism and also to the possible uses of its results when setting parameters for the children's books chosen to be distributed to public schools by the Ministry of Education in Brazil.
\end{abstract}

\section{KEYWORDS}

children's literature; people with disabilities; discourse analysis.

\section{CUARENTA AÑOS RETRATANDO LA DISCAPACIDAD: ENCUADRES Y ENFOQUES DE LA LITERATURA INFANTIL Y JUVENIL BRASILEÑA}

\section{RESUMEN}

Esta investigación analizó ciento cincuenta libros de literatura, publicados en los últimos cuarenta años, que representaban, en portugués, la discapacidad: tipos físicos, mentales o sensoriales. El análisis se realizó de acuerdo a los postulados de la Escuela Francesa de Análisis del Discurso. Fue constatado que los libros de las décadas de 1970 y 1980 eran de escritores profesionales, y más ideológicamente independientes. Los libros para niños escritos por autores brasileños a partir de la década de 1990 se llevaron a cabo por escritores principiantes que utilizaron su experiencia con la deficiencia. Ellos, por lo tanto, centraron sus objetivos en la provisión de información científica y en la emisión de mensajes moralizantes sobre la vida con discapacidad. Este compromiso político ocurrió debido a la mejor ejecución estética de las obras, que no conservaron premisas artísticas. Las informaciones técnicas comprometieron la prioridad lúdica de la literatura y no tuvieron éxito, pues hubo graves errores conceptuales en los libros. Esta investigación se justifica por la contribución semiótica dada a la crítica literaria y también a los posibles usos de sus resultados en el ajuste de los parámetros que eligen los libros para niños distribuidos a las escuelas públicas por el Ministerio de Educación de Brasil.

PALABRAS CLAVE

literatura infantil; persona con discapacidad; análisis del discurso. 
Nas últimas décadas, o mercado editorial brasileiro tem publicado uma quantidade crescente de livros infantis que exploram o tema da diferença e, bastante especificamente, da deficiência nas suas variadas expressões: surdez, cegueira, deficiência física, síndrome de Down, autismo etc. Nessas mesmas décadas assistimos à organização dos movimentos políticos em favor da defesa dos interesses das pessoas com deficiência.

Desde então, a escola regular, alçada à responsabilidade de fazer acontecer a inclusão social das pessoas com deficiência, pareceu assim ter encontrado nessas ferramentas didáticas, comumente aplicadas ao aprendizado da leitura, um valor de uso igualmente instrumental na missão de educar para a tolerância frente à diferença.

Há estudos precursores que investigaram o lugar do personagem deficiente nos livros infantis (Orjasaeter, 1981; Ziegler, 1980). Um estudo bastante abrangente está em língua inglesa (Pisent, 1997). Há trabalhos interessantes também sobre livros em língua espanhola (Camels, 2009), em árabe (Aisawi, 2010) e sobre livros infantis com personagens deficientes no idioma coreano (Yoo, 2010).

Pesquisadores que analisaram livros infantojuvenis em língua portuguesa ora se restringiram aos aspectos da surdez e da deficiência auditiva (Karnopp, 2010; Silveira, 2000), ora se limitaram a oferecer um levantamento descritivo mas pouco explicativo (Cruz, 1991), cobrindo uma quantidade pequena de livros (Noronha, 2006; Real, 2009; Souza, 2011), circunscrevendo-se aos contos de fadas (Guerra, 2009; Tanaka, 2007) ou estudando uma amostra de livros recortados em um período já muitos anos distante do tempo presente (Amaral, 1992).

\section{METODOLOGIA}

O estudo, objeto do presente relato, trata-se de uma pesquisa do tipo documental, cuja amostra foi composta por 150 livros infantis em língua portuguesa, originalmente ou traduzidos. Os livros foram identificados por buscas exaustivas em livrarias físicas e virtuais, em bibliotecas e sebos. A amostra, portanto, é seguramente representativa do universo de livros infantis e juvenis do mercado editorial brasileiro que retrata a deficiência.

Os critérios de inclusão para compor a amostra requereram que os livros de literatura, cumulativamente, fossem indicados para crianças ou adolescentes (segundo assinalamentos da própria editora); estivessem escritos em língua portuguesa, editados no Brasil (ainda que fossem fruto de traduções); retratassem formas de deficiência (física, mental, sensorial, múltipla) experimentadas tanto por crianças e/ou adolescentes quanto por adultos, ou mesmo por animais, desde que antropomorfizados.

A análise foi encaminhada, a princípio, nos modos de uma análise de conteúdo. Isso permitiu o registro quantitativo de regularidades presentes no conjunto amostral das obras. Esse registro foi obtido por meio de um formulário contendo uma série de quesitos que pré-qualificavam as narrativas, os enredos, as imagens, os autores, as editoras, segundo categorias analíticas específicas.

Os achados dessa primeira etapa produziram gráficos e quadros ou seja, nos modos típicos de uma análise de discurso. O significado do termo "contexto de 
realização" refletiu-se no confrontamento do livro - como um produto cultural com a conjuntura educacional, no que tangia às políticas de inclusão vigentes em cada momento histórico.

O sentido explorado do conceito de discurso foi aquele próprio à Escola Francesa de Análise do Discurso, que tem nas obras de Charaudeau (2008) e de Maingueneau (2000) a melhor atualização. Nesses termos é que se justificou - na análise dirigida aos livros especificamente infantis (aqueles endereçados a crianças pequenas) - o escrutinamento dos textos como uma coleção tanto de palavras escritas quanto de imagens - gravuras, fotografias, demais ilustrações -, assim como do arranjo gráfico que orienta o olhar do leitor e faz resultar cada livro como um objeto visual único (Oliveira, 2008).

\section{RESULTADOS}

A primeira investida de ordenamento dos livros infantojuvenis permitiu enxergá-los segundo a quantidade de obras que aborda cada um dos diferentes tipos de deficiência, conforme apreciável no Gráfico 1.

Essa primeira forma de segmentação distinguiu, em uma coluna separada, aqueles livros cujas narrativas faziam referência, simultaneamente, a mais de um tipo de deficiência. No Gráfico 1, então, a soma dos diferentes segmentos corresponde ao montante dos livros analisados.

Uma reclassificação que distribuiu os livros do segmento "mais de um tipo" (representado pela menor coluna do gráfico) para que estes se fizessem constar com aqueles que compõem os distintos segmentos de abordagem - deficiência visual, deficiência mental, deficiência auditiva, deficiência física - pode ser apreciada no

\section{Gráfico 1 - Distribuição dos livros por tipo de deficiência especificamente retratada}

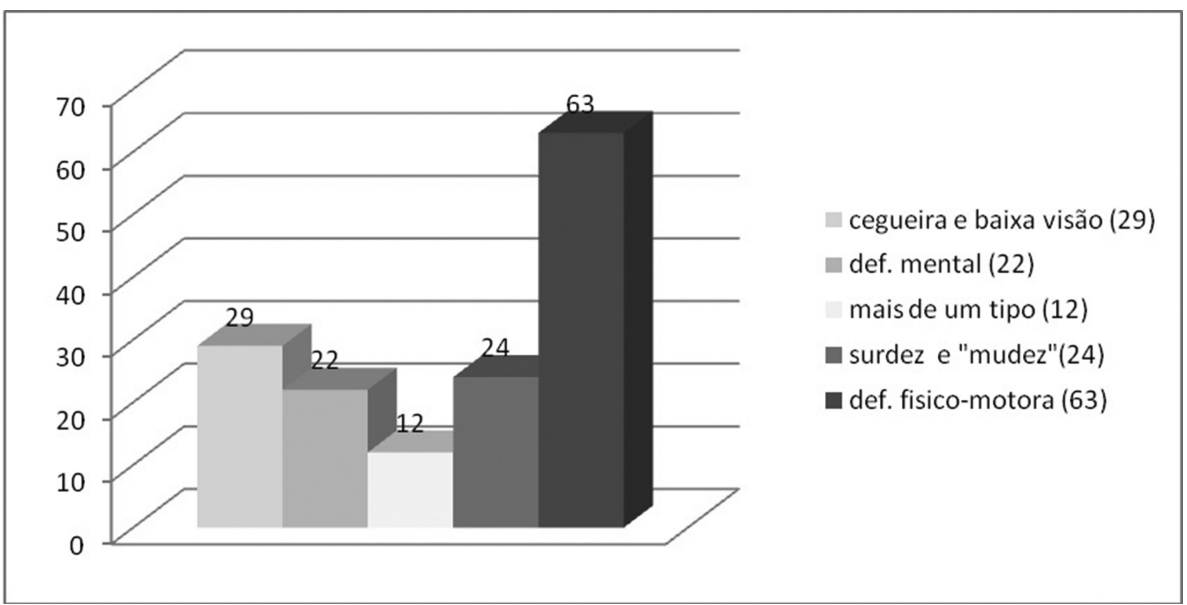

Fonte: Banco de dados da pesquisa.

Elaboração da autora. 
Gráfico 2 - Distribuição dos tipos de deficiência no montante dos livros

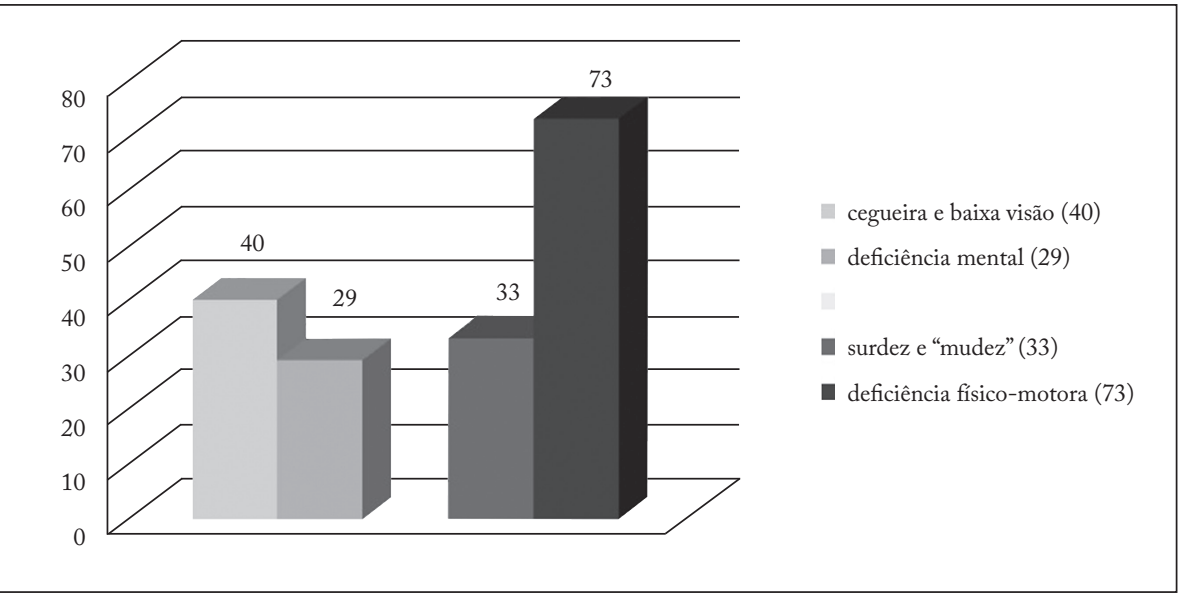

Fonte: Banco de dados da pesquisa.

Elaboração da autora.

\section{Gráfico 3 - Livros infantis que tematizam a deficiência} versus ano de lançamento da primeira edição

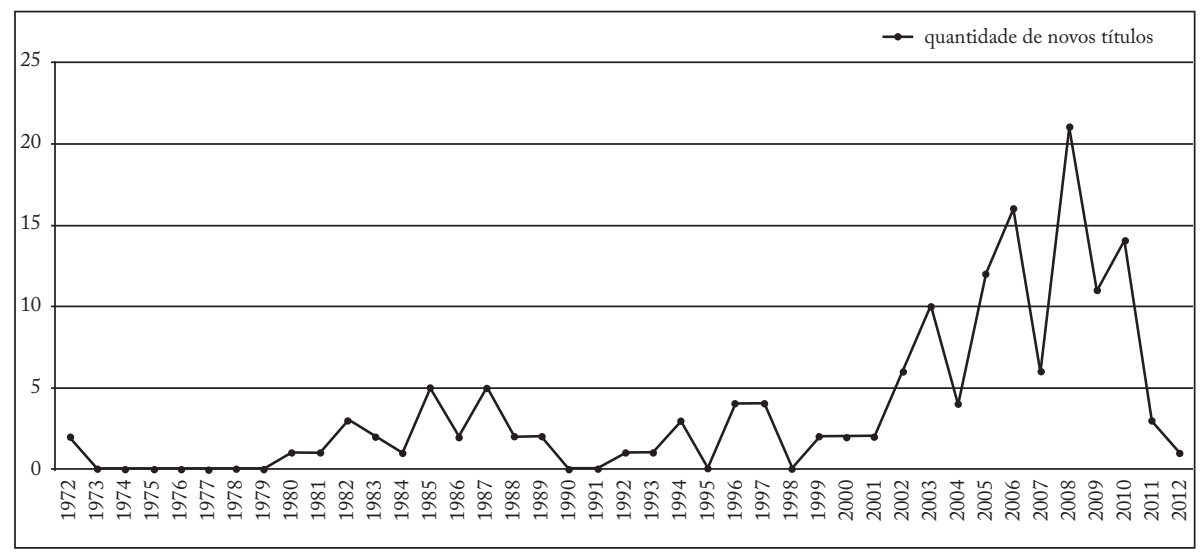

Fonte: Banco de dados da pesquisa.

Elaboração da autora.

Gráfico 2, no qual se observa que a deficiência física mantém-se como a condição majoritariamente retratada nos livros infantis e juvenis brasileiros das últimas quatro décadas.

A segunda investida de ordenamento da amostra de livros infantojuvenis permitiu enxergá-la em um movimento de localização temporal que evidencia a distribuição, ao longo dos anos, da data da primeira publicação das obras. É o que pode ser apreciado no Gráfico 3. 


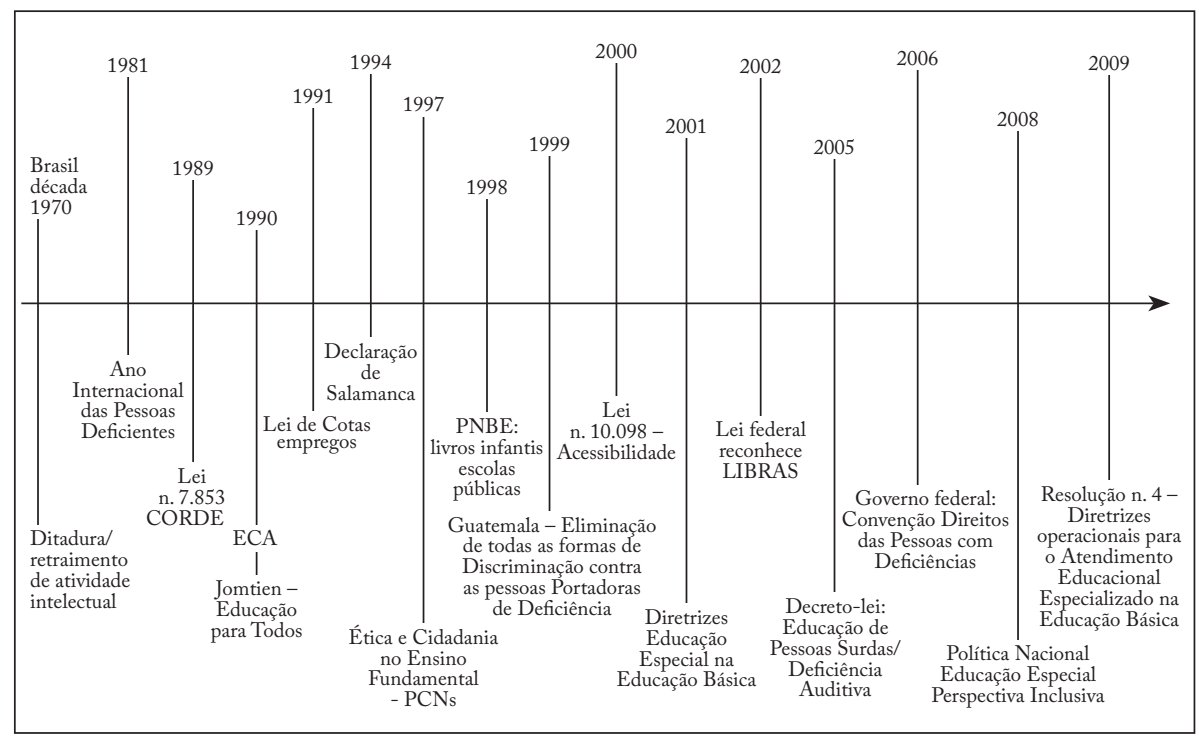

Figura 1 - Linha do tempo: eventos relacionados à deficiência, à educação e aos direitos humanos. Fonte: Banco de dados da pesquisa.

Elaboração da autora.

O pico no ano de 2008, assim como outras variações ao longo das décadas, pode ser mais bem entendido se for apreciado de modo sobreposto à Figura 1.

É importante que a leitura da distribuição do surgimento de novos títulos de livros, feita então à luz dos eventos marcantes no plano social ao longo desses anos, considere igualmente o caráter cumulativo desses eventos. Assim, por exemplo, tanto o lançamento da Política Nacional de Educação Especial na Perspectiva Inclusiva haverá de ter contribuído para o grande número de novos títulos no ano de 2008 como, em verdade, a soma contínua de uma série de circunstâncias anteriores que vinham constituindo todo um contexto favorável também o fez.

Além disso, há de se levar em conta, igualmente, fatores explicativos da ordem das razões do mercado livreiro, das políticas editoriais e de toda uma conjuntura nacional que faz ver que, para todas as temáticas e faixas etárias de leitores, houve um aumento crescente na publicação de novos títulos de livros nos últimos quarenta anos.

Nesse sentido, um dos fatores que merece destaque é o Programa Nacional Biblioteca da Escola (PNBE). Esse programa prevê a seleção de conjuntos de livros de literatura - chamados acervos literários - que são distribuídos gratuitamente às bibliotecas das escolas de educação básica do país (Brasil, 2008). Mobiliza recursos vultosos que, somente no ano de 2007, permitiram a distribuição de mais de sete milhões de livros, que representaram a cifra de 46 milhões de reais (Maciel, 2008, p. 12). A resposta que as editoras brasileiras dão aos editais do PNBE está objetivada na inscrição que fazem dos títulos que julgam ser os mais adequados a esse público. 
A terceira investida de ordenamento da amostra de livros infantojuvenis permitiu enxergá-la na proporção do tipo de autores que assinaram as obras. Para fins do presente estudo, foram considerados, de modo mutuamente excludente, na forma de duas categorias. A primeira, aqui denominada "escritores profissionais", foi composta por aqueles escritores da amostra que, de maneira isolada ou cumulativamente: possuíam um grande número de títulos de sua autoria em circulação; haviam recebido prêmios ou menções honrosas, segundo os meios especializados; e/ou possuíam sua presença comentada em um compêndio crítico sobre literatura infantojuvenil (Coelho, 2006), para o caso dos autores brasileiros. Considerou-se ainda condição necessária para esse enquadramento que o autor já viesse escrevendo para aquele segmento de público, de maneira tal que, preferencialmente, os livros não estivessem atrelados à deficiência ou aos direitos das minorias.

A via de acesso às informações que embasaram essa categorização dos escritores deu-se, então, por meio da busca em páginas de sebos virtuais, os quais, na medida em que se especializaram em livros usados e antigos, permitiram identificar menções a eventuais outros títulos do conjunto da obra de um determinado autor e, assim, julgá-lo na quantidade de livros que porventura assinou. Do mesmo modo, a conferência em páginas de livrarias virtuais também favoreceu esse dimensionamento da produção literária de cada autor.

A segunda categoria, aqui chamada "escritores iniciantes", foi definida por contraposição aos escritores da primeira categoria. Ela compunha-se daqueles que, assim sendo, possuíam um pequeno número de obras em circulação no mercado, ou assinavam obras (por vezes uma grande quantidade) que evidenciavam que o autor em questão inaugurava sua carreira com os títulos presentes na amostra analisada e/ou haviam se lançado no mercado com títulos atrelados à questão de outras minorias discriminadas. Consequentemente, eram inexistentes premiações ou referências meritórias emitidas por entidades literárias chanceladas para tanto.

Constatou-se, nesse sentido, que, dos 108 autores diferentes identificados, 56 eram escritores "profissionais" de livros infantojuvenis, sendo 41 brasileiros e 15 estrangeiros. Os escritores “iniciantes", que então assinaram 52 dos livros analisados, eram absolutamente todos brasileiros. As obras, às quais correspondem sua autoria, foram distribuídas na proporção dos anos da primeira edição, conforme pode ser apreciado no Gráfico 4, que evidencia a disposição dos escritores “iniciantes" em escrever para crianças e contemplar o tema da deficiência, marcadamente a partir da década de 1990.

$\mathrm{Na}$ sequência, buscou-se identificar a remissão autoral, ou o "lugar de fala", daqueles 52 autores classificados como escritores “iniciantes" pela presente pesquisa. Os achados podem ser vistos no Gráfico 5 .

As próximas seções responderão pela etapa do estudo anunciada como sendo a de análise do discurso, uma vez que os resultados já apresentados até aqui poderão efetivamente ser interpretados segundo as condições sócio-históricas de ocorrência dos fenômenos que os forjaram. 
Gráfico 4 - Distribuição da autoria “escritor iniciante” em livros infantojuvenis que tematizam a deficiência

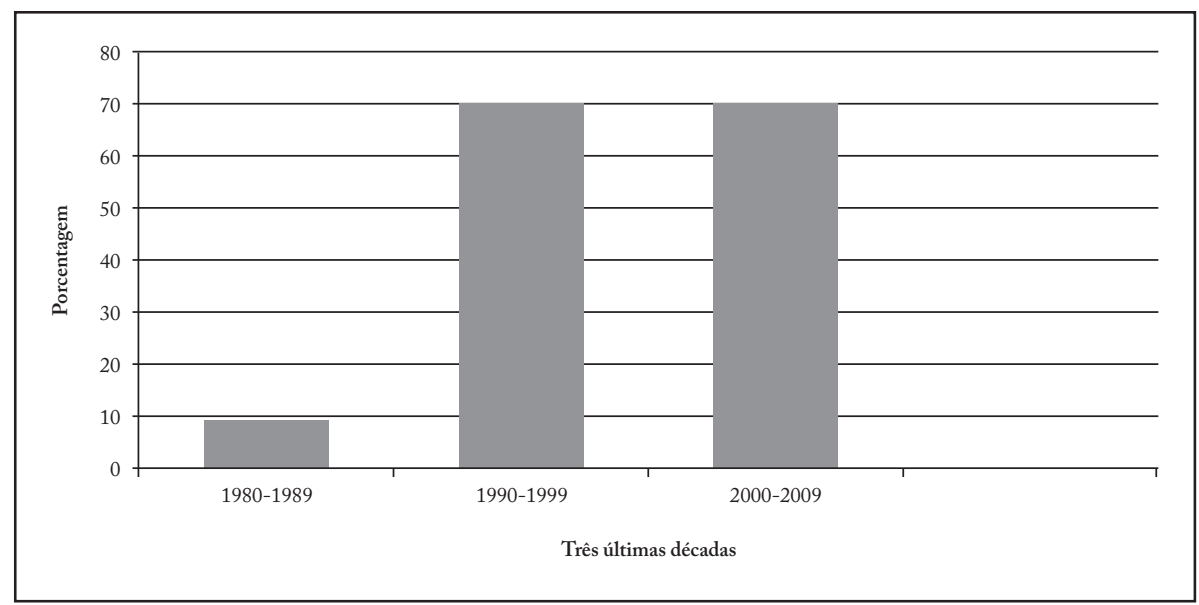

Fonte: Banco de dados da pesquisa.

Elaboração da autora.

Gráfico 5 - Autoridade de escritores iniciantes para a escrita de livros infantojuvenis sobre deficiência

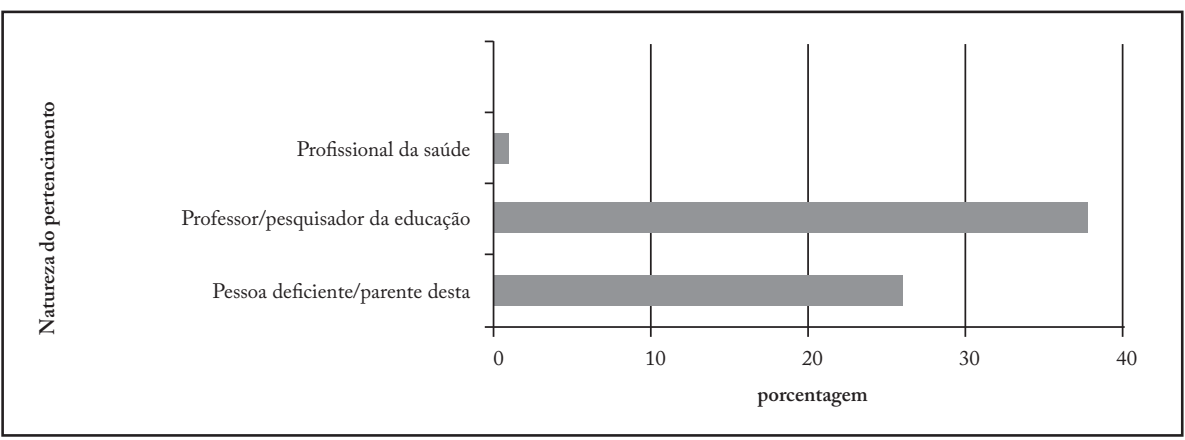

Fonte: Banco de dados da pesquisa. Elaboração da autora.

\section{A PREDOMINÂNCIA DA DEFICIÊNCIA FÍSICA}

A existência de uma expressiva quantidade de livros infantojuvenis que retratam a deficiência física, quando comparada àquela de livros que retratam outros tipos de deficiência, conforme observado nos Gráficos 1 e 2 da seção de resultados, merece um debruçar analítico mais demorado. Assim, pois, a necessidade das crianças pequenas de identificar concretamente a deficiência pode ajudar a justificar essa super-representação da deficiência física na literatura infantojuvenil. Um estudo 
de revisão bibliográfica sobre concepções e atitudes de crianças não deficientes em relação às deficiências concluiu que:

Alguns tipos de deficiência parecem ser percebidos mais facilmente pelas crianças ainda na pré-escola, enquanto outros passam sem ser percebidos até o primário. As crianças mais novas reagem a aspectos visíveis das outras pessoas. No caso da deficiência, aspectos físicos e necessidade de equipamentos são percebidos mais prontamente por elas. Apenas mais tarde notam deficiências mentais e, posteriormente, problemas de conduta. (Vieira; Denari, 2007, p. 35)

Logo, o anseio dos editores em atender à expectativa do público infantil, somado à facilidade com que se faz representar essa condição a partir de suportes materiais, uma vez que "em se tratando de deficiência física, há muitos sinais pictóricos disponíveis ao artista; cadeiras de rodas, muletas, tutores ou suportes amarrados às pernas, perna de pau, membros mecânicos, próteses, bengalas, membros ausentes" (Reily, 2008, p. 252), pode explicar esse cenário simbólico.

Um estudo que analisou uma amostra significativa de livros didáticos (Barros, 2007) constatou que representações acerca da deficiência física também eram expressivamente mais presentes, quando comparadas àquelas sobre os demais tipos de deficiência. $\mathrm{O}$ estudo chamou atenção para o fato de que isso se dava a despeito da população brasileira recenseada não ter, na deficiência física, sua maior prevalência numérica. A tentativa de resposta para aquele achado produziu uma reflexão que pode ser facilmente aplicável à interpretação dos presentes resultados. E se considerarmos que a distância entre livros didáticos, objeto daquele estudo, e livros de literatura infantil, objeto do presente estudo, está cada vez mais estreita, esse empréstimo explicativo é bastante plausível.

O que haveria na deficiência física, que a leva a ser representada nos livros didáticos de uma maneira tal que não corresponde à realidade epidemiológica de uma população? Talvez a facilidade de simbolizá-la - quando para tanto basta uma cadeira de rodas como significante. [...] Então, resta pensar, talvez, que esta submissão do espectro das deficiências à deficiência do tipo físico seja, apenas, um desdobramento da percepção superficial que tem o senso comum acerca da dimensão da experiência da deficiência. (idem, p.72)

Prosseguir na busca de explicação para essa hegemonia representacional da deficiência física levou a observar a distribuição das datas da primeira publicação, de modo segmentado por diferentes recortes de tempo, para cada conjunto de livros que retratam os diferentes tipos de deficiência. Constatou-se que, mesmo nos anos em que pouco se escrevia sobre a deficiência para o público infantojuvenil (até porque pouco se escrevia para crianças, de um modo geral), privilegiava-se a deficiência do tipo física, conforme pode ser apreciado no Quadro 1.

Essa quantidade aumentada de livros infantojuvenis que retratam a deficiência física nas décadas de 1970 e 1980 faz coincidir, justamente, com a época em que o Brasil começava a absorver os frutos da extensa mobilização política deflagrada 


\section{Quadro 1-Tipo de deficiência presente em livros} infantojuvenis das décadas de 1970 e 1980

\begin{tabular}{|l|r|}
\hline \multicolumn{1}{|c|}{ Tipo de deficiência } & \multicolumn{2}{c|}{ Porcentagem } \\
\hline Físico-motora & $32 \%$ \\
\hline Mental & $19 \%$ \\
\hline Auditiva & $10 \%$ \\
\hline Visual & $8 \%$ \\
\hline
\end{tabular}

Fonte: Banco de dados da pesquisa.

Elaboração da autora.

por ativistas estadunidenses, os quais, incapacitados fisicamente em consequência da Guerra do Vietnã, expunham sua condição de oprimidos socialmente (Diniz, 2007).

Olhar as décadas de 1970 e 1980 no Brasil é ver também uma nação que, do ponto de vista da saúde pública, lutava pela erradicação da poliomielite - a chamada paralisia infantil -, cujo último caso haveria de ser registrado em 1989. Logo, no imaginário social do brasileiro e, por conseguinte, no de seus escritores e leitores potenciais, a figura da criança sequelada pela poliomielite, "paralítica", como normalmente se dizia, apoiada em muletas ou "prostrada" em uma cadeira de rodas, era a que mais imediatamente representava a ideia da deficiência.

Vale, nesse sentido, recordar um sucesso da música popular brasileira da década de 1970, intitulado Cadeira de rodas, cuja letra é reproduzida a seguir:

Sentada na porta,/Em sua cadeira de rodas ficava./Seus olhos tão lindos, / Sem ter alegria,/Tão triste chorava./Mas quando eu passava/ A sua tristeza chegava ao fim./Sua boca pequena,/No mesmo instante,/Sorria pra mim./Aquela menina era a felicidade/Que eu tanto esperei,/Mas não tive coragem e não lhe falei/ Do meu grande amor e agora,/Por onde ela anda, eu não sei./ (refrão) Hoje eu vivo sofrendo e sem alegria./ Não tive coragem bastante pra me decidir./Aquela menina em sua cadeira de rodas/Tudo eu daria pra ver novamente sorrir. (Mendes, 1975)

Fernando Mendes, compositor e intérprete dessa canção, alcançou o auge de sua carreira musical ao ser premiado com um Disco de Ouro obtido com a venda de mais de 250 mil cópias do disco que continha a faixa Cadeira de rodas (trinta anos depois, Caetano Veloso, ao escolher um sucesso de Fernando Mendes para regravar, haveria, contudo, de preferir Você não me ensinou a te esquecer, talvez para evitar o apelo piegas, hoje tido como politicamente pouco correto, da música Cadeira de rodas).

Desse modo, ainda que a cadeira de rodas não seja, do ponto de vista da reabilitação, o único ou o mais utilizado dos recursos terapêuticos, é ela quem mais se faz representar na literatura infantojuvenil quando se retrata a deficiência físico-motora. Essa predominância pode ser observada no Gráfico 6, que registrou os diferentes tipos de deficiência físico-motora distribuídos pelos livros infantis da amostra estudada. Somadas as frequências das representações que se fizeram na forma do "cadeirante", constata-se que ocupam 73\% das narrativas. 


\section{Gráfico 6 - Diferentes tipos de deficiência físico-motora representadas em livros infantojuvenis}

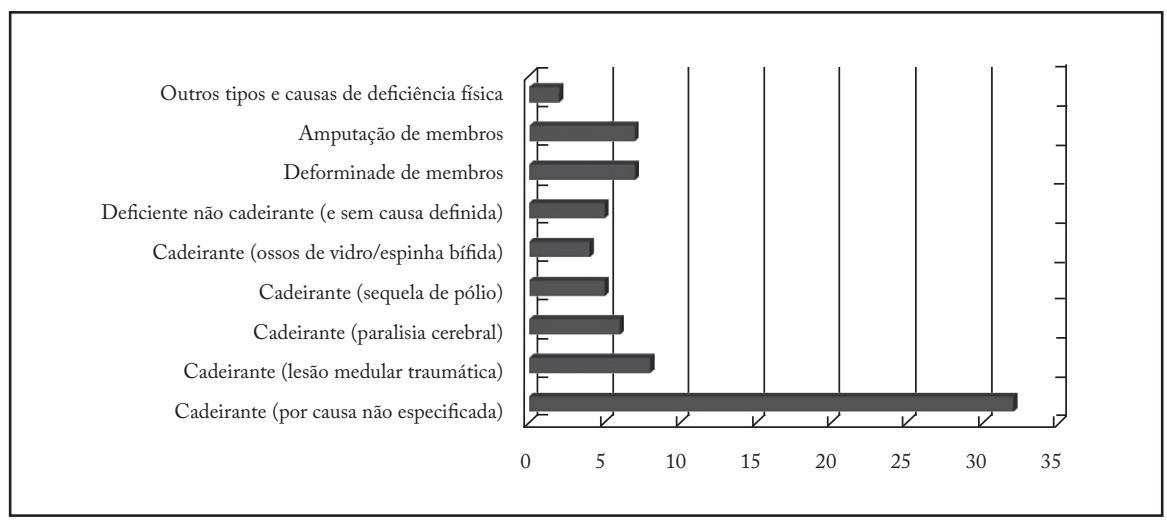

Fonte: Banco de dados da pesquisa.

Elaboração da autora.

\section{A PREDOMINÂNCIA DO PANFLETO POLÍTICO, DA CARTILHA EDUCATIVA E DO MANUAL DE BOAS MANEIRAS}

Uma das hipóteses de trabalho que motivou a pesquisa supôs uma incompatibilidade de funções na maioria dos livros infantis que retratam a deficiência, qual seja: moralizar e ao mesmo tempo proporcionar prazer aos sentidos a partir do exercício da leitura. Haveria, assim - paradoxalmente -, pouca literatura nos livros de literatura infantil que tematizam a deficiência.

Um caminho possível para confirmar essa hipótese seria a análise, do ponto de vista da crítica literária, da elaboração narrativa das histórias de cada um dos livros da amostra. Isso se daria para fins da identificação, e posterior registro de frequências, de indicadores da qualidade estética das obras, tais como a coesão textual, a construção das personagens, a originalidade do argumento, a dramaticidade do enredo e a presença efetiva de conflito, clímax e desfecho. Contudo, dadas as dimensões censitárias da amostra, acabou-se optando por outras vias de análise.

A primeira via foi aquela que, partindo da premissa de que a ausência da dimensão artística na literatura que versa a deficiência se daria em favor da presença aumentada das dimensões política/pedagógica/sanitária, buscou, então, elementos demarcadores desses planos. $\mathrm{O}$ tom, por assim dizer, panfletário dessa literatura foi sugerido, desse modo, pela urgência de grande parte dos livros em apresentar a deficiência ao leitor. Isso ficou evidenciado, por conseguinte, pela antecipação do propósito da mensagem à custa de palavras que descreviam expressamente a deficiência nos títulos, nos subtítulos e/ou nas contracapas, que se faz presente, então, em $70 \%$ dos livros.

O referido apelo panfletário ficou igualmente evidenciado quando da análise mais depurada dos livros infantojuvenis que abordam a surdez e a deficiência auditiva. Julgá-los requer que se entenda antes o modo como os livros para crianças do 
mercado editorial brasileiro posicionam-se discursivamente ao abordar a surdez e/ ou a deficiência auditiva. Eles estão fortemente segmentados em três grandes grupos de propostas ideológico-pedagógicas: a) que preconizam o uso das LIBRAS; b) que preconizam a oralização; c) que não se enquadram em nenhum dos segmentos ideológicos descritos anteriormente.

No primeiro e maior grupo, estão contidos catorze títulos. No segundo grupo, aquele que se posiciona, explícita ou implicitamente, em favor da oralização, estão contidos cinco títulos. No terceiro e menor segmento, estão dois livros, indiferentes a essa polarização.

Observou-se, daí, que quatro títulos da vertente preconizadora do uso das LIBRAS são livros apologéticos que beiram o proselitismo, todos publicados por uma editora confessional luterana. $\mathrm{O}$ anseio panfletário dos livros os levou a incorrer em dois absurdos ontológicos graves. $\mathrm{O}$ primeiro faz parecer que o indivíduo surdo já nasce sabendo sinalizar:

Após algum tempo, nasceu o patinho surdo e os cisnes ficaram olhando para ele. A mamãe cisne falou: "Oi! Bem-vindo à lagoa!" Mas o patinho surdo nada respondeu. A mamãe insistiu: "Oi!". Mas ele continuava sem falar! O casal ficou apreensivo! O patinho então sinalizou: “Oi, mamãe! Oi, papai!” Os cisnes ficaram assustados! (Karnopp; Rosa; Silveira, 2005b, p. 19)

O segundo absurdo faz parecer que a condição natural do ser humano é não ouvir e não falar:

Um dia Adão e Eva estavam passeando pelo jardim e olharam para a árvore. [...] eles decidiram provar do fruto proibido. Adão e Eva comeram e imediatamente houve uma transformação: perceberam que estavam nus. Preocupados e envergonhados, usaram suas mãos para se esconder. Foi então que, impedidos de usarem as mãos, foram obrigados a usar a fala! (Karnopp; Rosa; Silveira, 2005a, p. 22-26, grifo meu)

Interrogar a retórica das mensagens empregadas na descrição da deficiência, com vistas a identificar se haveria compatibilidade com o ideário simbólico das crianças às quais os livros se dirigiam, também permitiu encontrar evidências que reforçaram a afirmação da predominância da pregação moral por sobre a reflexão ética nas mensagens dirigidas ao leitor infantil.

Estudos que investigaram valores e concepções manifestas de crianças normais em relação à deficiência nos mostram que, a depender da faixa etária e, por conseguinte, da maturidade psíquica para o desenvolvimento do senso moral, elas percebem e expressam compreensões sobre a deficiência bastante díspares.

[...] As crianças de sete anos ressaltaram a falta, a ausência de membros ou funções; as de oito anos citaram a necessidade de cura para a convivência social; as de nove anos mostraram-se dispostas a ajudar; e as mais velhas apresentaram discursos de caridade e demonstraram ter piedade pelas pessoas com deficiência. [...] As (crianças) mais novas, [tinham] certa dificuldade de compreendê-lo 
[o caráter permanente da deficiência], imaginando que as deficiências pudessem ser curadas ou fossem passageiras. (Vieira; Denari, 2007, p. 38)

Não obstante o reconhecido e necessário exercício de alteridade que um livro deve estabelecer ao dialogar com seus leitores possíveis, alguns dos livros infantis analisados não anteciparam essa ampla variedade de modos de conceber a deficiência por parte das crianças. Pois, ainda que, a princípio, mantivessem o cuidado editorial de predefinir faixas etárias para o enquadramento de cada livro, este se limitava a compatibilizar os pequenos leitores em função de suas capacidades de interpretação dos códigos linguísticos.

Não é fácil escrever em primeira pessoa, principalmente quando o autor é um adulto, e o leitor, uma criança. Corre-se o perigo de tentar imitar a linguagem infantil e abusar da puerilidade. O risco aumenta, quando o narrador apresenta-se como uma criança, cujo vocabulário e domínio da sintaxe são ainda relativamente reduzidos. $\mathrm{O}$ resultado pode ser um texto simplório, se o escritor quiser facilitar demais, ou inverossímil, se o narrador revelar um conhecimento linguístico impróprio para a idade. (Zilberman, 2005, p. 36)

Os livros infantis de Werneck (1994a, 1994b) são exemplos típicos da falta de verossimilhança, não exatamente relativa ao âmbito do domínio linguístico por parte da criança que narra, mas por pressupor uma maturidade moral que não se realiza em idade tão tenra. A fala que se imputa ao garoto que é narrador nesses livros está repleta de juízos de valor acerca da irrelevância do eventual mau desempenho escolar de um colega de escola que tem síndrome de Down. Ocorre que tais valorações não são próprias do julgamento de crianças nessa idade. São termos da reflexão de um adulto, e de um adulto ajustado ao conteúdo político da causa dos direitos dos deficientes e da afirmação da tolerância frente à diversidade.

A outra via de análise que ajudou a afirmar a predominância do panfleto em detrimento da literatura foi aquela que interpretou o achado segundo o qual há uma maior proporção de escritores brasileiros "iniciantes" $(\mathrm{n}=52)$ em relação aos escritores brasileiros "profissionais" ( $n=41)$, no tocante à autoria dos livros. Esse artifício lógico não pressupôs, necessariamente, uma incapacidade artística dos escritores "iniciantes" ou falta de talento para produzir literatura de qualidade; mas antes uma indisposição para fazê-lo, dada a pressa em lançarem-se no mercado. Pois muitos desses escritores não só estrearam no ramo da literatura infantojuvenil a reboque do apelo midiático que o tema da deficiência imprimiu aos seus livros, como assim vêm se mantendo.

\section{A LAMENTÁVEL PRESENÇA DE EQUÍVOCOS CONCEITUAIS}

É comum que aquele escritor amador, típico da década de 1990 em diante, seja professor da educação básica (algumas vezes da educação especial) ou do ensino superior. São, assim, em geral, pedagogos, havendo ainda alguns linguistas e/ ou especialistas em línguas de sinais. 
Mas infelizmente essas justificações de legitimidade dos escritores que respondem pela autoria de grande parte da literatura infantojuvenil contemporânea que retrata a deficiência não são garantia da ausência de incorreções científicas nos livros. Estas podem ser encontradas, por exemplo, nas seguintes passagens:

A síndrome de Down afeta aproximadamente uma em cada 550 crianças. Todas as pessoas estão sujeitas a ter um filho com síndrome de Down, independente da raça ou condição socioeconômica. Ainda não se conhece a causa dessa alteração genética, mas já se sabe que não existe responsabilidade do pai ou da mãe para que ela ocorra. (Honora, 2008, p. 32, grifo meu)

Fica evidente que a autora do livro citado, ou aquele que fez sua revisão, ou ainda aquele que se responsabilizou pelo conteúdo dos posfácios didático-científicos (bastante comuns nas edições publicadas a partir da década de 1990) tomou como sendo uma coisa e a mesma as alterações genéticas e as alterações cromossômicas.

Grosso modo, a diferença entre umas e outras é que as alterações cromossômicas são em virtude da ausência de cromossomos, enquanto nas alterações genéticas o problema está na falha em apenas um gene ou poucos deles, que são apenas pequeníssimas partes de um cromossomo. Além disso, as disfunções genéticas não são descobertas na gravidez, diferentemente das alterações cromossômicas, que assim podem ser. Pelo fato de a alteração estar presente em cromossomos inteiros ou em parte significativa deles, um grande número de genes está comprometido. Desse modo, não há tratamentos para a alteração em si, apenas para as consequências dela. Pelo mesmo motivo apresentado, não há cura para tais alterações. No entanto, em se tratando das alterações genéticas, embora não haja ainda cura definitiva, há perspectivas otimistas a serem alcançadas em terapias com células-tronco.

Outro exemplo de erro conceitual é apreciável em um livro que, embora tenha sido originalmente escrito por autor estrangeiro, contém um posfácio explicativo assinado por uma educadora brasileira, do qual justamente se extraiu o trecho a seguir:

O que é a síndrome de Down? Trata-se de uma deficiência que acomete um em cada 700 bebês que vem ao mundo. [...] A origem dessa alteração na constituição do corpo é desconhecida, e sua transmissão não é hereditária, porém provoca variadas perturbações. (Huainigg, 2006a, p. 28, grifo meu)

O erro aqui está em afirmar que a síndrome de Down não é hereditária, quando, em verdade, existe sim uma forma da síndrome de Down que o é. Ela representa cerca de $3 \%$ dos casos e corresponde àqueles em que a trissomia é causada pelo que se chama translocação entre os cromossomos 14 e 21, gerando um cromossomo híbrido. Essa translocação ocorreu em um dos genitores da pessoa com Down. Nesse caso, o pai ou mãe é apenas um portador da translocação, ou seja, não tem Down mas fabricará espermatozoides ou óvulos que carregam a possibilidade de produzir um bebê com a síndrome ou de estender esse risco a gerações futuras de sua linhagem.

Por menos que se espere tal domínio conceitual daqueles que não são profissionais de saúde ou que não necessariamente têm formação em ciências biomédicas, 
alguma responsabilidade com o conteúdo teórico de suas obras literárias é bem-vinda, principalmente quando se arvoram a dissertar acerca dos aspectos médicos das deficiências que abordam e/ou ainda quando anunciam o valor educativo de seus livros. A tendência de aproximação de muitos desses livros de literatura com manuais didáticos de ciências encontra-se problematizada a seguir:

Um aspecto que se destaca em diversos paratextos examinados é a utilização de um discurso científico voltado para informar sobre as diferenças tematizadas no texto principal da obra. [...] informaçôes cientificas (dados epidemiológicos; a probabilidade de um professor e/ou aluno ter em sala de aula um anão, um surdo, um Down, um cego; estatísticas e possíveis explicações para determinadas condições etc.), que parecem ter sido retiradas diretamente de um manual técnico ou, ainda, de um livro didático. (Silveira; Bonin; Ripoll, 2010, p. 103, grifo do original)

Erros conceituais estão presentes também nos livros infantojuvenis que retratam a deficiência auditiva e/ou a surdez. Os livros infantis que preconizam o uso da LIBRAS o fazem com pouca ou nenhuma ênfase ao aprendizado da língua portuguesa como segunda língua - LP2. Um deles até mesmo ensina (em espaço que destaca esse propósito pedagógico, pois que localizado em apêndice ao final do livro) equivocadamente o que seria, no âmbito da educação de surdos, o bilinguismo. Pois, em vez de esclarecer que o caráter dual, relativo ao prefixo "bi" da palavra, refere-se ao uso simultâneo da LIBRAS para comunicação e da língua portuguesa, apenas para leitura silenciosa e escrita, o livro faz constar que: "Quando as crianças aprendem a Libras e também são treinadas para usar a língua portuguesa, elas ficam sendo 'bilíngues' e então conseguem fazer leitura labial, isto é, conseguem 'ler' o que os outros estão falando pelo movimento dos lábios" (Huainigg, 2006b, p. 31) .

Mais uma vez, chamo atenção para o fato de que, não obstante o autor do citado livro, Nós falamos com as mãos, não seja brasileiro e, portanto, pudesse ser desconsiderado do escopo classificatório que identificou o perfil do escritor que assina livros infantis sobre deficiência no Brasil, seu posfácio pedagógico é assinado por consultor, que é - efetivamente - uma escritora brasileira.

Nos livros sobre surdez/deficiência auditiva há ainda um erro conceitual bastante comum. Tanto aqueles de um segmento quanto do outro fazem parecer que a comunicação em língua de sinais se dá principalmente pelo uso do alfabeto de sinais, o qual, na verdade, é apenas acessório. A datilologia é tomada pela sinalização em LIBRAS como se fossem uma coisa e a mesma.

Essas ocorrências foram interpretadas em razão da época em que os livros foram pela primeira vez editados. Pode-se então dizer que aqueles publicados até o final da década de 1990, talvez porque ignorassem a possibilidade linguística da LIBRAS, mantêm o discurso em torno apenas da oralização. A análise considerou, igualmente, que os livros infantis publicados por editoras confessionais não católicas (luteranas, presbiterianas, batistas, evangélicas) são expressamente afirmadoras do orgulho surdo, diferentemente daqueles publicados, por exemplo, pela Editora Paulinas ou pela Paullus. 
Há ainda, no conjunto da amostra analisada, livros que contêm uma apropriação conceitual equivocada bastante peculiar. Contam histórias que giram em torno de um personagem que é "mudo". Trata-se, contudo, de uma mudez sem associação alguma à deficiência auditiva, à deficiência mental ou a transtornos globais do desenvolvimento, assim como sem nenhuma possível associação à disartria grave, eventualmente presente na paralisia cerebral. Epidemiologicamente falando, é uma mudez que não existe. Socioantropologicamente falando, será sempre presente: é a mudez do senso comum, de referência quase folclórica no imaginário popular (por essa razão, inclusive, três dos livros foram, nesta pesquisa, classificados na categoria deficiência auditiva (Barros, 2006; Góes, 1982, 2003). Entendeu-se, pois, que, em princípio, o público leitor faria aproximações de sentido daquele distúrbio da fala do protagonista com a "mudez" que vulgarmente se supõe associada à surdez.

Clássicos da literatura universal exploraram bastante essa figura, no "mudinho do Zorro", por exemplo. Mas, se a literatura infantil, comprometida com causas das minorias, pretende explorar essa figura, é importante demarcá-la fortemente no campo da ficção, sob o risco de contradizer os anseios educativos que tal literatura reclama. Do mesmo modo, haverá de cuidar para que os termos "mudo" e "surdo-mudo", expressamente desaprovados pela comunidade militante e/ou estudiosa sobre a surdez, sejam banidos dos livros infantis. Assim sendo, não mais seriam encontrados, como o foram, nos livros Criança especial, criança diferente (Nery, 1997, p. 17) e Gabriel e as visitas especiais (Katsuya, 2005, p. 11)

\section{A ATUALIZAÇÃO DO ESTEREÓTIPO NO REDUCIONISMO MULTICULTURALISTA}

Falar na atualização de um fenômeno requer um olhar que o acompanhe na passagem do tempo. Falar, então, na atualização do estilo estereotipado que teria caracterizado os livros infantojuvenis que vêm retratando a deficiência requer enxergá-lo no passado para situá-lo no presente, ainda que sob outras versões.

Esse movimento de localização temporal teve como ponto de partida os estudos de Amaral (1992), que, tendo avaliado livros para crianças e adolescentes de autores brasileiros, publicados entre 1971 e 1991, afirmou que havia naquela literatura elementos que configuravam representações do corpo desviante, as quais, nos termos enunciados pela autora, seriam "geradoras ou propiciadoras de cristalizações de estereótipos, denunciadoras de atitudes e preconceitos frente à diferença corporal, bem como perpetuadoras de leituras maniqueístas e estigmatizantes" (idem).

Supor que estereótipos tipicamente atrelados à deficiência, como aquele da superação heroica, do poder da "força de vontade" ou do peso da "sina", tenham se atualizado em outras versões requereu também apreciar comparativamente os dois grandes subgrupos de livros que retratam a deficiência físico-motora: obras cuja primeira edição datava do final da década de 1980 e obras editadas a partir da década de 1990. Optou-se por analisar especificamente esse tipo de deficiência porque, conforme já assinalado, além de seus títulos constituírem o conjunto mais 
numeroso, estavam no mercado mesmo nos períodos de pouca produção literária sobre a temática.

Reafirmando aquilo já identificado por Amaral (idem), constatou-se, então, que até meados da década de 1980 era bastante comum que os livros trouxessem, no decurso de suas narrativas (e até nos paratextos que constituíam contracapas, dedicatórias e prefácios), termos como defeituoso, grotesco, inválido, entrevado, aleijado, aleijão, empedernido, paralítico e deformado.

Contudo, considerando que as palavras escolhidas por um autor expressam os valores da sociedade em que ele vive e o ajudam, portanto no compromisso de manter um diálogo legível com os leitores de seu tempo, a análise aqui empreendida preferiu não julgar, tão simplificadamente, aqueles livros de modo negativo. Preferindo, assim, interpretar a presença daquelas expressões como parte dos recursos linguísticos de que o autor deve se valer para alcançar seu público, esta pesquisa as entendeu como factíveis, senão necessárias, do ponto de vista estético.

Logo, não por acaso, a busca pelo enquadramento categorial dos autores que publicaram até meados da década de 1980 permitiu constatar que eram - em sua grande maioria - escritores profissionais consagrados. Muitos dos livros daquele período receberam sucessivas edições, o que indica não só a abertura do mercado literário como a receptividade do público, tanto no passado como no presente. Por essa razão, quase todos os autores desse primeiro período aparecem citados no compêndio de novecentas páginas que pretendeu reunir e comentar o que houvesse de mais representativo na literatura infantojuvenil brasileira (Coelho, 2006).

Se um olhar recontextualizado oferece bons álibis às obras que fundaram o tema da deficiência na literatura infantil, o mesmo não se pode dizer sobre aquelas que foram publicadas da década de 1990 em diante. Nessas é possível identificar uma quantidade significativa do que aqui se denominou "clichês narrativos" que apelam para a normalização da deficiência.

Essa normalização se dá por meio da aproximação da diferença do deficiente com aquela diferença contida no espectro de variação próprio da espécie humana. Está presente, por exemplo, no livro O pequeno rei Artur: "Mas não somos todos diferentes (!) Uns magros e morenos; outros gordos e loiros”(Cyreno, 2007,p. 8); ou em Cada cabeça é um mundo: "Mas isso não quer dizer nada porque TODO mundo é diferente de todo mundo" (Gouveia, 2003a, p. 4, grifo do original). A qualidade incapacitante - e ao mesmo tempo distinguidora e identitária - da síndrome de Down, da cegueira ou da surdez aparecem, então, minoradas sob a justificativa de fazer-se melhor aceitá-las. Um exemplo está presente, por exemplo, no livro Meu amigo Down na rua: "Esse errinho de fabricação não causa mal a ninguém" (Werneck, 1994c, p. 11). O estudo de Silveira, Bonin e Ripoll (2010, p. 105-106) fazem colocações interessantes a esse respeito:

O que salta aos olhos é o modo como os paratextos informativos silenciam no que diz respeito ao retardo mental (e à microcefalia e ao baixo peso do cérebro) na síndrome de Down - mencionando, em grande parte dos casos, que o afetado "é igual a todo mundo", "aprende como todo mundo" e se "desenvolve naturalmente" -, bem como o modo como o discurso biomédico acaba atribuindo 
positividade a essa diferença, como se ela fosse apenas mais um traço distintivo, como qualquer outro, da espécie humana.

Essa estratégia de eufemização da deficiência, que parece servir de antídoto para o tratamento estereotipado da imagem do deficiente, fez, por conseguinte, com que vários livros resistissem à enunciação explícita dos termos que definem as deficiências sobre as quais tratavam. Logo, dos 40 livros que contaram histórias que retratavam a deficiência visual, 20 permitiram a presença da palavra "cego" ou suas variantes. E dos 30 livros que abordaram a deficiência auditiva em suas narrativas, apenas 13 se permitem expressamente conter a palavra "surdo", "surda" ou "surdez". Esse recurso de retórica constituiu um paradoxo interessante, pois muitos dos livros que continham essas "reservas semânticas" eram os mesmos que se apressavam em apresentar as intenções normativas da obra, trazendo nos título e subtítulo da capa, ou na ficha catalográfica, as expressões "diferente", "diferença”, "especial”, "igual” e "deficiência”.

\section{A ATUALIZAÇÃO DO MELODRAMA NA MODERNA “AUTOAJUDA"}

Olhar as décadas de 1970 e 1980 fez ver que o romance de mistério e as novelas policiais, típicas da literatura juvenil daquela época (Zilberman, 2005), haviam incorporado o adolescente com deficiência, ora no papel do intrépido detetive que investigava crimes, ora em personagens outros que desvendavam a trama. Assim o foram com as obras de Rey (1981, 1982, 1983), Mott (1985a, 1985b) e Oliveira $(1985,1986)$. Mas olhar aquele período fez ver também o tom melodramático de outra parte da literatura destinada à infância naqueles anos:

O doutor avançou para mim: - Este branquelo? - perguntou. - É... - respondeu dona Madalena. - Pois levanta-se! Eu peguei as muletas, levantei: - Atire isso fora e ande. - Não, doutor! Eu não posso encostar o pé esquerdo no chão. - Estou dizendo: jogue as muletas e ande! - Aí, doutor! Só ouvi contar disto da boca de Jesus Cristo. (Prado, 1984, p. 46)

- Só uma pessoa gosta de mim como eu sou, Anna. Você não se incomoda que eu seja aleijado, que eu tenha essa cabeça grande. Você não se incomoda que minhas mãos às vezes tremam e eu derrame a comida no chão. (Vasconcelos, 1982, p. 21)

O menino acordou com a sensação exata de que é inútil viver. Já está crescido, uns doze anos, e vê a diferença entre ele e os outros meninos. E percebe que é um peso, talvez não o filho exato para um casal que só tem um filho. (Carvalho, 1980, p. 35)

- Sua perna ainda não sarou? - Não. E não vai sarar nunca. Só se acontecer um milagre. - Que pena! Nunca poderá correr! - Já não me importo. Aprendi a aceitar o meu defeito. (Marques, 1985, p. 20) 
Todavia, a despeito de reconhecer o pendor lacrimoso do livro Menino preso na gaiola, Nelly Coelho refere-se a ele da seguinte maneira:

$\mathrm{Na}$ linha realista pretendida pela coleção, este Menino Preso na Gaiola, apesar da contenção sentimental lograda pelo autor, é antes de tudo um livro pungente. [...] Narração em terceira pessoa. Estilo direto que, na maior parte do relato, consegue travar a natural emotividade que a matéria provocaria, substituindo-a pela agressividade ou pela revolta que invade o espírito do menino. $\mathrm{O}$ inconformismo com a situação de inferioridade a que a paralisia o condenava, em lugar de se revelar negativo, afirma-se altamente positivo. (Coelho, 2006, p. 92)

Logo, mais interessante que julgar o melodrama das narrativas dos primeiros livros foi constatar, na busca por sua eventual persistência nos livros escritos a partir do início da década de 1990, que ele havia se atualizado no ramo literário da autoajuda.

A rigor, um livro de autoajuda é aquele que se propõe a instrumentalizar o leitor para que ele alcance - de modo supostamente autônomo, ou à custa apenas de recursos psíquicos internos - a superação de dificuldades como a dependência química, o consumo compulsivo ou o apego amoroso obsessivo. Sua escrita se vale de uma retórica persuasiva caracterizada por frases prontas, fáceis de serem retomadas pelo leitor na forma da contínua evocação de seus conteúdos, o que constitui, também, a essência operativa do livro. Herdeira dos princípios de condicionamento que ancoram a psicologia comportamental e tributários do sugestionamento que instrui a psicologia positiva, a literatura de autoajuda é a panaceia moderna, que trocou a igreja pela farmácia e esta agora pela livraria.

Caracteristicamente, a narrativa de salvação laica da autoajuda é textualmente dirigida à pessoa que virá a ler o livro. Situa-se, do ponto de vista das classificações editoriais, distinguida dos romances e das biografias, sendo um gênero cujos livros são por vezes denominados "manuais". O discurso é direto, e a mensagem claramente destinada ao leitor. Logo, entender a interpretação que o presente estudo fez requer que se considere que o efeito de autoajuda das obras literárias ficcionais que retratam a deficiência se dá por vias subsidiárias. Uma delas seria aquela que, ao proporcionar o confrontamento do leitor com o personagem deficiente, favorece ao primeiro a experiência de breve êxtase contido na constatação da sua normalidade, que se segue ao compromisso moral de, daí por diante, afirmar a própria existência mais positivamente. Enxergar o que seriam, então, verdadeiros problemas ao olhar a vida de um deficiente teria o poder, assim, de redimensionar os problemas pessoais do leitor.

Martins (2006) nos mostra que a ancoragem na pessoa do deficiente como pretexto para um exercício de transcendência espiritual já fora, muito antes, inaugurada pela caridade cristã. Suas reflexões nos ajudam a ver ainda que também não há novidade no modo utilitário como o leitor - uma pessoal normal - opera tal interesse pelas pessoas com deficiência, haja vista a similaridade com os motivos que aproximariam deficientes e não deficientes. 
[...] a acção caritária resulta menos de uma continuidade com os valores de amor ao próximo, advogados por Jesus, do que de uma ênfase na necessidade de, por essa via, o crente alcançar uma forma de redenção e a salvação. Portanto, em larga medida, os sujeitos eleitos como "objectos" da caridade, entre os quais se encontravam as pessoas com deficiência, são consagrados como provações divinas, como veículos para o exercício da virtude, no fundo, meios para a salvação das almas dos seus benfeitores. (idem, p. 55)

A funcionalidade de autoajuda manifestada pelos livros que retratam a deficiência, especialmente por aqueles que, destinados ao público adolescente, são lidos igualmente por jovens adultos, cumpre seu papel, também, na medida em que traduz o humanismo das confissões religiosas e dos tratados políticos internacionais para versões leigas e mais mundanas. A promessa de solidariedade que o leitor então pactua com o outro - de início, o deficiente, e, por extensão, todos os excluídos - o faz acreditar no merecimento da ajuda que porventura reclama para si. Essa confiança no sucesso, ou na justeza do pedido, é a mesma, por princípio, contida na fé, que daí poderá se renovar tanto na oração como na leitura de autoajuda. Acerca desse caráter pararreligioso do gênero autoajuda, Stoll (2009, p. 17) afirma que este é comumente "Destinado a um público pouco afeito a fidelidades institucionais, cujas ligações com a religiosidade se expressam por meio de engajamentos transitórios, práticas sincréticas e múltiplas combinações de técnicas terapêuticas e místicas".

Uma vez que a essência mobilizadora da autoajuda está em apostar no poder do ser humano para a transposição de adversidades, além do modelo narrativo típico de enumeração de diretrizes para o reordenamento de condutas pessoais,

Também se encontra no gênero, é fato, narrativas em primeira pessoa, histórias de vida, em que o sujeito relata a descoberta de suas forças mais íntimas e a maneira como as empregou para superar seus problemas individuais ou narra como passou por um processo de mudança interior, tornando-se, por conta própria, uma nova pessoa. Através dessas narrativas, os autores relatam uma lição de fé, apresentam uma visão própria e pregam a autoestima, preconizando aos leitores que eles façam o mesmo que eles fizeram. (Rüdiger, 2010, p. 166)

Logo, justificar o movimento analítico-interpretativo que aqui aproximou os livros infantojuvenis que retratam a deficiência aos modernos manuais de autoajuda permite também destacar, nos primeiros, alguns trechos que nos ajudam a entender como as histórias contadas favorecem o acionamento, no leitor, daquela mesma resposta buscada nos manuais de autoajuda. Assim, por exemplo, no livro O muro (Braz, 2003, p. 24), que conta a história de um garoto em cadeiras de rodas, é possível ler:

Já não existem muros na minha frente. Ou melhor, eles estão aparecendo todo dia. É a melhor parte da vida - o desafio, a superação, o desejo de ir sempre mais além -, aquilo que a torna tão fascinante. Porque a vida é feita mesmo de muros, 
muitos muros, grandes muros, pequenos muros, tantos muros, muros de todos os tipos, muros que a gente tem de ultrapassar [...]

No livro Criança genial (Cotes, 2005, p. 18), que discorre, em breves passagens, sobre as experiências de várias crianças com deficiência, é possível ler: "A Beatriz não pode escutar e mesmo assim não para de estudar. Vence seus limites e mostra que a felicidade não tem idade".

Eis que o leitor experimenta, então, um misto de alívio e glorificação - por saber-se em melhor situação que o deficiente e por reconhecer-se tão capaz, em princípio, de ultrapassar um desafio.

Usar uma cadeira de rodas ou caminhar com muletas pode se tornar um desafio mais difícil para você. Contudo, você é capaz de fazer muitas outras coisas. Você apenas as fará de maneira diferente. Todo mundo tem seus desafios a enfrentar. Aprender como superá-los fará com que você queira gritar: "Ei, galera, eu estou aqui! Eu posso fazer qualquer coisa que eu quiser”. (Muldoon, 2011, p. 4)

E assim Matheus aprendeu a lutar com mais força para superar as dificuldades que o faziam infeliz. Descobriu que tinha mil outros motivos para ser alegre e amar a vida acima de tudo. Uma novidade mudaria sua vida: Matheus amadureceu o sonho de ser atleta e passou a fazer parte de um time de basquetebol em cadeira de rodas. (Carraro, 2007, p. 32)

Nesses termos, a exortação do "Eu" como senhor de possibilidades do sucesso pessoal, pedra de toque da pregação de autoajuda (Rüdiger, 2010), faz-se reverberar nas narrativas dramáticas de muitos livros infantojuvenis que contam histórias sobre a deficiência. "O corpo humano é do tamanho da vontade da gente, dos sonhos e da fé que temos em chegar aonde quisermos ir. Por isso, mesmo pequenino, Caio é um gigante!" (Gouveia, 2003b, p. 18). "A Aline se esforçou ao máximo e hoje é a única bailarina com Síndrome de Down no mundo! Ela tem os olhos verdes mais lindos que eu já vi. E uma linda história de amor, disciplina e superação" (Tomaz, 2012, p. 42).

Nesse ponto da argumentação, é interessante retomar a coincidência existente entre o fato de as últimas duas décadas - aquelas em que se localizou o que aqui se chamou de atualização do melodrama no gênero da autoajuda - concentrarem, relativamente ao tipo de autores infantojuvenis que retratam a deficiência, um grande número de escritores iniciantes, em detrimento de escritores profissionais. Rüdiger (2010, p. 66) nos ajuda, então, a ver que, não por acaso, "eles [os escritores de autoajuda], via de regra, não são autoridades científicas, políticas ou literárias”.

\section{CONSIDERAÇÕES FINAIS}

Apesar do tom denunciador deste artigo, é importante, nesse ponto, deixar claro que não se pretendeu desautorizar o papel que possuem os livros infantis na reafirmação do respeito à diferença. O objetivo da pesquisa traduziu-se, antes, 
naquele de questionar as certezas confortavelmente estabelecidas em torno da qualidade e do alcance útil desses livros como instrumento de positivação da deficiência.

O anseio de crítica almejado se fez expresso, em parte, nos termos da autora citada a seguir:

A maioria de nós talvez não tenha problemas em relação à necessidade de livros mostrarem pessoas "incapacitadas" como pessoas reais, com direito a tanta dignidade quanto qualquer outra pessoa. O risco aqui é o de a simpatia tornar-se proteção, com a produção resultante de livros inferiores. Livros sobre temáticas mais obviamente políticas podem ser problemáticos, mas tentar evitar que as crianças os encontrem seria também um erro [...]. Mas [as crianças] devem estar cientes de que um autor, com um espectro de preconceitos humanos normais, escreveu o livro, de que um editor decidiu que valia a pena economicamente publicá-lo e de que um livreiro achou que valia a pena vendê-lo. Elas precisam entender que nada é livre de valores, nem os livros, nem os programas de TV, nem as revistas, e que ninguém é livre de preconceitos, nem seus professores, nem seus pais, nem elas mesmas. (Pinsent, 1997, p. 142)

Em que pese o argumento de que inexiste uma narrativa isenta de ideologia, ou seja, de que toda história contada estará sempre - de alguma forma - lastreada nos princípios normativos de uma cultura, o que aqui se contra-argumentou em relação a uma parcela dos livros infantis que tematizam a tolerância à deficiência é o caráter comumente prescritivo que assumiram nessa função. Pois, na ausência dos arquétipos e atavismos construídos e desconstruídos no decurso das várias gerações que contaram e recontaram histórias, restou aos livros infantis de hoje inculcar valores à custa de lições apressadas.

A importância da pesquisa aqui relatada passou, também, pela necessidade de preenchimento de uma lacuna na produção do conhecimento sobre a relação entre ideologia e livros para crianças. Muito embora haja uma longa tradição de estudos sobre os modos de expressão da diversidade humana nos livros infantis, o conhecimento produzido sobre a representação da deficiência na literatura infantil reclamava uma ampliação da amostra e uma atualização no recorte de tempo, de modo que abrangesse o número mais representativo possível dos títulos disponíveis para as crianças, quer seja nas livrarias, quer seja nas bibliotecas. Estas, porque preservam em seus acervos a memória do conjunto de obras sobre uma tema, permitem que títulos que já fizeram parte da amostra de pesquisas anteriores sejam revistos em nova análise. Os resultados, assim como apropriações que se possam fazer das estratégias de análise empregadas, poderão desdobrar-se em impacto para o campo dos estudos sociolinguísticos. Isso se dá em razão da possibilidade de problematizar o conhecimento produzido nessa área, acrescentando, pois, elementos lógico-conceituais aos estudos semióticos sobre livros infantis, uma vez que os referentes simbólicos em questão - doença 
e deficiência - são incomuns às análises interpretativas normalmente encaminhadas pela crítica literária.

Necessário destacar ainda o impacto econômico dos achados. Esses estão situados na contribuição possível à sofisticação dos critérios de escolha adotados pelo Ministério da Educação (MEC) para o PNBE. Os critérios de escolha dos livros adotados - preliminarmente pelas editoras e definitivamente pelo MEC sinalizam não apenas as concepções de infância com as quais o mercado editorial brasileiro e a tecnocracia governamental operam, mas também as concepções de respeito pela diferença à infância associadas, tendo em vista a forte atração dos livros infantis contemporâneos pelos temas da ética e da cidadania. Como parte do que se entende por diferença comporta o fenômeno da deficiência; então enxergá-la mais criteriosamente naquele livro infantil cujo acesso é subsidiado com dinheiro público passa a ter importância superlativa.

Do mesmo modo, quanto mais bem instrumentados estiverem os professores da educação básica para julgar esses livros, mais satisfatórias são as chances de sucesso na inclusão escolar de alunos com deficiência. Isso se dá em um contexto que prescinde a presença necessária e evidente de crianças com deficiências nas escolas regulares, uma vez que a inclusão social que se almeja e os valores de tolerância e respeito que se pretendem disseminar devem perseverar para além dos muros da escola e dos momentos circunstanciados de aula.

Nesses termos se pode enunciar, então, que o impacto social derivado também pode se dar na possibilidade de municiar a sociedade civil organizada na forma das entidades de defesa dos interesses das pessoas com deficiência com ferramentas verdadeiramente sensíveis que superem o proselitismo corrente. Pois o modelo panfletário de afirmar os direitos tem um alcance que é de curto prazo, uma vez que não logra transformações mais duradouras, verdadeiramente reflexivas, da condição de exclusão dessa parcela da população.

Cabe reconhecer, por fim, uma limitação de natureza epistemológica do estudo realizado. Trata-se do fato de que, com a presente pesquisa, mais uma vez (se considerarmos a tradição dos estudos de qualificação de livros infantis) foi a perspectiva do adulto aquela que instrumentou o julgamento de livros que se destinam à criança. Isso acaba por recrudescer o viés historicamente inscrito na produção de artefatos culturais para a infância. Discorrendo a esse respeito, a reflexão a seguir destacada é bastante ilustrativa:

[...] a produção cultural preparada para a criança mostra-lhe não aquilo que ela, criança, seleciona, mas no máximo o que o aparelho produtor julga ser do interesse dela. Em tais condições, o olhar da criança sobre o mundo achase desviado, dirigido para objetos tidos pelos adultos produtores como merecedores de suas atenções. (Perrotti, 1990, p. 96)

Logo, como sugestão de desdobramentos futuros desta pesquisa, recomenda-se submeter o conjunto de livros ao crivo da escolha livre de crianças e adolescentes, para os quais aquela literatura, em essência, se dirige. 


\section{REFERÊNCIAS}

Aisawi, S. A. Voices of the minorities: children's literature and disability. In: Congreso Internacional, 32., 2010, Santiago de Compostela. Anais... Santiago de Compostela: IBBY, set. 2010.

Amaral, L. A. Espelho convexo: o corpo desviante no imaginário coletivo, pela voz da literatura infantojuvenil. 1992. Tese (Doutorado em Psicologia) - Universidade de São Paulo, São Paulo, 1992.

BARros, A. Discursos e significados sobre as pessoas com deficiências nos livros didáticos de português: limites na comunicação de sentidos e representações acerca da diferença. Revista Brasileira de Educação Especial, Marília: ABPEE, v. 13, n. 1, p. 61-76, 2007.

Barros, M. T. B. O menino dos oito óculos. São Paulo: Viva e Deixe Viver, 2006.

Brasil. Ministério da Educação. Programa Nacional Biblioteca da Escola (PNBE): leitura e bibliotecas nas escolas públicas brasileiras/Secretaria e Educação Básica, Coordenação-Geral de Materiais Didáticos. Elaboração de Andréa Berenblum e Jane Paiva. Brasília: Ministério da Educação, 2008.

Braz, J. E. O muro. São Paulo: Paulinas, 2003.

Carraro, F. Quero viver! São Paulo: FTD, 2007.

Carvalho, A. Menino preso na gaiola. Belo Horizonte: Comunicações, 1980.

Camels, D. La discapacidad del héroe: diferencia y discapacidad en las narraciones dedicadas a la infancia. Buenos Aires: Biblos, 2009.

Charaudeau, P. Linguagem e discurso. São Paulo: Contexto, 2008.

Coelno, N. Dicionário crítico da literatura infantil e juvenil brasileira. São Paulo: Companhia Editora Nacional, 2006.

Cotes, C. Criança genial. São Paulo: Paulinas, 2005.

CRUz, M. O deficiente e as diferenças na literatura infantil e juvenil: bibliografia. São Paulo: Secretaria Municipal de Cultura, 1991.

Cyreno, L.; Paterno, S. O pequeno rei Arthur. São Paulo: Paulinas, 2007.

Dinız, D. O que é deficiência. São Paulo: Brasiliense, 2007.

Góes, L. P. Trim. São Paulo: Melhoramentos, 1982. . A flauta do sótão. São Paulo: Paullus, 2003.

Gouveia, L. A. Cada cabeça é um mundo. Salvador: Fala Menino!, 2003a. Rodas gigantes. Salvador: Fala Menino!, 2003b.

Guerra, R. Doença mental e os estranhos personagens da literatura infantil. Revista de Ciências Humanas, Florianópolis: EDUFSC, v. 43, n. 2, p. 445-489, out. 2009.

Honora, M. Uma amiga diferente. São Paulo: Ciranda Cultural, 2008.

Huainigg, F.-J.Juntos somos ótimos. São Paulo: Scipione, $2006 a$. 
Nós falamos com as mãos. São Paulo: Scipione, 2006b.

Karnopp, L. B.; Rosa, F.; Silveira, C. H. Adão e Eva. Canoas: Editora da Ulbra,2005a. ;_________ Patinho surdo. Canoas: Editora da Ulbra, 2005b.

Karnopp, L. B. Produções culturais de surdos: análise da literatura surda. Cadernos de Educação, Pelotas: FaE/PPGE/UFPel, n. 36 p. 155-174, maio/ago. 2010.

Katsuya, A. C. Gabriel e as visitas especiais. São Paulo: Callis, 2005.

Maciel, F. I. P. O PNBE e o CEALE: de como semear palavras. In: PAiva, A.; Soares, M. Literatura infantil: políticas e concepções. Belo Horizonte: Autêntica, 2008. p. 7-20.

Maingueneau, D. Termos-chave da análise de discurso. Belo Horizonte: Editora da UFMG, 2000.

Marques, L. O coelhinho deficiente. São Paulo: Salesiana Dom Bosco, 1985.

Martins, B. S. "E se eu fosse cego?": narrativas silenciadas da deficiência. Porto, Portugal: Edições Afrontamento, 2006.

Mendes, F.; Wilson, J. Cadeira de rodas. Intérprete: Fernando Mendes. In: Mendes, F. Cadeira de rodas. Direção artística:____. São Paulo: EMI Music Brasil, 1975. 1 disco sonoro (45min) 33 1/3 rpm, estéreo, 12 pol. Lado A, faixa 1.

Мотт, O. B. No beco do sabão. São Paulo: Atual, 1985a. . O clube dos bacanas. São Paulo: Atual, 1985b.

Muldoon, K. Sim, eu posso! São Paulo: Paulus, 2011.

Nery, E. Criança especial, criança diferente. Belo Horizonte: Mazza Edições, 1997.

Noronha, L. F. A representação da deficiência na literatura infantojuvenil em tempos de inclusão. 2006. Dissertação (Mestrado em Distúrbios do Desenvolvimento) Universidade Presbiteriana Mackenzie, São Paulo, 2006.

Orjasaeter, T. The role of children's books in integrating handicapped children into everyday life. Paris: UNESCO, 1981. (Studies on books and reading, n. 1)

Oliveira, G. J. A próxima vítima. São Paulo: Salesiana Dom Bosco, 1985. . O enigma da casa de vidro. São Paulo: Atual, 1986.

Oliveira, I. (Org.). O que é qualidade em ilustração no livro infantil e juvenil: com a palavra o ilustrador. São Paulo: DCL, 2008.

Prado, L. J. A. Afinal, é a felicidade. São Paulo: FTD, 1984.

Perrotti, E. Confinamento cultural, infância e leitura. São Paulo: Summus, 1990.

Pinsent, P. Children's literature and the politics of equality. London: David Fulton Publishers, 1997.

ReAL, D. C. A literatura infantojuvenil nas águas da inclusão escolar: navegar é preciso. 2009. Dissertação (Mestrado em Educação) - Universidade Federal do Rio Grande do Sul, Porto Alegre, 2009. 
Reily, L. Músicos cegos ou cegos músicos: representações de compensação sensorial na história da arte. Caderno CEDES, Campinas: UNICAMP, v. 28, n. 75, p. 245-266, maio/ago. 2008.

Rey, M. Mistério do Cinco Estrelas. São Paulo: Ática, 1981. . O rapto do garoto de ouro. São Paulo: Ática, 1982. . Um cadáver ouve rádio. São Paulo: Ática, 1983.

RüDIgeR, F. Literatura de autoajuda e individualismo: contribuição ao estudo de uma categoria da cultura de massas. Porto Alegre: Gattopardo, 2010.

Silveira, R. H. Contando histórias sobre surdos (as) e surdez. In: Costa, Marisa Vorraber (Org.). Estudos culturais em educação. Porto Alegre: Editora da UFRGS, 2000.

Silveira, R. M. H.; Bonin, I.T.; Ripoll, D. Ensinando sobre a diferença na literatura para crianças: paratextos, discurso científico e discurso multicultural. Revista Brasileira de Educação, Rio de Janeiro: ANPEd; Campinas: Autores Associados, v. 15, n. 43, p. 98-108, jan./abr. 2010.

Souza, F. C. "Como lobo na pele de cordeiro": discursos das diferenças em textos narrativos infantis sobre a pessoa com deficiência. 2011. Dissertação (Mestrado em Educação Especial) - Universidade de São Paulo, São Paulo, 2011.

SToll, S. J. Encenando o invisível: a construção da pessoa em ritos mediúnicos e performances de "autoajuda". Religião e Sociedade, Rio de Janeiro: ISER, v. 29, n. 1, p. 13-29, 2009.

TANAKa, L. M. Contos de fadas e a construção da imagem simbólica coletiva frente à inclusão escolar. 2007. Dissertação (Mestrado em Distúrbios do Desenvolvimento) - Universidade Presbiteriana Mackenzie, São Paulo, 2007.

Tomaz, A. F. A bailarina especial. São Paulo: Panda Books, 2012.

VAsconcelos, J. M. O veleiro de cristal. São Paulo: Melhoramentos, 1982.

Vieira, C. M.; Denari, F. E. O que pensam e sentem crianças não deficientes em relação às deficiências e à inclusão: revisão bibliográfica. Revista da FAEEBA, Salvador: Educação e Contemporaneidade, v. 16, n. 27, p. 31-40, jan./jun. 2007.

Werneck, C. Meu amigo Down em casa. Rio de Janeiro: WVA, 1994a. . Meu amigo Down na escola. Rio de Janeiro: WVA, 1994b. . Meu amigo Down na rua. Rio de Janeiro: WVA, 1994c.

Yoo, S. O. Interactions between characters with and without disabilities in korean contemporary picture books. In: Congreso Internacional, 32. , 2010, Santiago de Compostela. Anais... Santiago de Compostela: IBBY, set. 2010.

Ziegler, C. R. The Image of the Physically Handicaped in Children's Literature. New York: Arno Press,1980.

Zilberman, R. Como e por que ler a literatura infantil brasileira. Rio de Janeiro: Objetiva, 2005. 


\section{SOBRE A AUTORA}

Alessandra Santana Soares e Barros é doutora em ciências sociais pela Universidade Federal da Bahia (UFBA). Professora adjunta da mesma instituição.

E-mail: alssb@ufba.br

Recebido em agosto de 2012

Aprovado em dezembro de 2013 